DOI: $10.15290 /$ bsl.2020.17.02

\author{
Zbigniew Kopeć \\ Instytut Filologii Polskiej \\ Uniwersytet im. Adama Mickiewicza w Poznaniu \\ e-mail: kzbsz@amu.edu.pl \\ ORCID: 0000-0003-4351-1137
}

\title{
Obyś cudze dzieci uczył (np. na Wołyniu lub Polesiu)! O szkole we wschodnich województwach międzywojennej Polski
}

Ksawery Pruszyński pisząc o krainie swojego pochodzenia i urodzenia ${ }^{1}$, koncentruje się z jednej strony na jej przeszłości, a z drugiej na współczesności. Opisując dawny Wołyń, podkreśla rozwój cywilizacyjny tego regionu, jego nierozerwalny związek z europejskimi prądami intelektualnymi, szerokie zainteresowania kulturalne mieszkających tam niegdyś obywateli ziemskich (przynajmniej niektórych), a także wysoki poziom działających tam placówek edukacyjnych, czego dowodem w jego wspomnieniu jest dawne Liceum Krzemienieckie. Tak widzianą, a dodajmy idealizowaną i gloryfikowaną przeszłość, przeciwstawia reportażysta Wołyniowi sobie współczesnemu, którego niedostatki i ułomności opisuje w reportażu pod znaczącym tytułem Był to niegdyś kraj bogaty². O Łucku np. pisze: „mury zamku Lubarta służą za podporę ćwiczebnym instalacjom straży pożarnej”, „na grobowym

1 K. Pruszyński, Na czarnym szlaku, w: tegoż, Wspomnienia, reportaże, artykuły, t. 1, Warszawa 2000.

2 K. Pruszyński, Był to niegdyś kraj bogaty, w: tegoż, Wspomnienia, reportaże, artykuły, t. 1, Warszawa 2000. Pierwodruk "Wiadomości Literackie” 1938, nr 5. Niektóre obecne tu wątki Pruszyński rozwija w reportażu: Czarna ksiega niszczenia Wołynia. Z dziejów walki z kultura, „Słowo” 1938, nr 135. 
miejscu dawnych kniaziów Wołynia i namiestników litewskich rośnie fasola, buraki i pietruszka pań komendantowych tejże straży”. „Zwierciadlana sala jednej z najpiękniejszych rezydencji w Polsce, Wiśniowca, służy za salę lokalnemu kinematografowi miasteczka za 150 zł miesięcznie. Jeden z najpiękniejszych w Polsce barokowych plafonów zniszczał, odkąd nad nim urządzono umywalnię". Liceum krzemienieckie, które - jak pisze - „było wyższą uczelnią, uniwersytetem pozbawionym jedynie tej nazwy", stało się zespołem szkół o "programie naszego szkolnictwa średniego, jeśli nie niższego" ${ }^{3}$. Wyimki z enumeracji reportażysty przytaczać można by jeszcze długo. Ich adresatem jest polska administracja wschodnich województw. Ciekawsze jest jednak to, że Pruszyński, który wskazuje na dawną świetność Wołynia i zestawia ją z mało satysfakcjonującą według swoich przekonań współczesnością, nie jest ani jedyny, ani tym bardziej pierwszy. Wcześniej w podobny sposób o tej krainie pisał Józef Ignacy Kraszewski w Wieczorach wołyńskich, odwołując się również do obecnej u Pruszyńskiego topiki wanitatywnej. Notuje Kraszewski swoje obserwacje: „same ruiny dokoła, ruiny dziejów, ruiny charakterów, ruiny rodzin, stanów, pamiątek" ${ }^{4}$. „Jedyne ślady życia - pisze Iwona Węgrzyn - pisarz znajduje w historii tej ziemi, jej teraźniejszość jest cmentarzyskiem, na którym króluje wszechwładna śmierć" ${ }^{5}$. Dla porządku trzeba zwrócić uwagę na pewną oczywistość. Mianowicie, obaj formułują swoje opinie w zupełnie różnych epokach. Świata, w którym żyje Pruszyński, czyli świata, w którym jest i niepodległa Polska, i radio, i automobil, i samolot, i pamięć iperytu, i faszystowskie Niemcy, i ZSRR ani Kraszewski, ani nikt $\mathrm{z}$ jego współczesnych $\mathrm{z}$ całą pewnością nie byłby $\mathrm{w}$ stanie nawet sobie wyobrazić. Może właśnie dlatego podobieństwo refleksji obu pisarzy na temat Wołynia i jego ludności uwypukla nie tylko stałość społecznych opinii i wyobrażeń dotyczących tego regionu i jego mieszkańców, ale i pewien paradoks. Otóż Kraszewski bezkrytycznie gloryfikuje przeszłość, widząc w teraźniejszości „cmentarz ludzi i charakterów”. Pruszyński natomiast z zachwytem pisze m.in. o czasach, w których żył Kraszewski, ale w Wołyniu sobie współczesnym dostrzega czasy skarlenia, upadku.

Kraszewski pisząc o autochtonicznych mieszkańcach Wołynia, stawia bardzo odważną, a chyba i nazbyt radyklaną, choć często powtarzaną tezę, że od czasów przedchrześcijańskich prawie wcale się nie zmienili:

\footnotetext{
3 K. Pruszyński, Był to niegdyś bogaty kraj, „Wiadomości Literackie” 1938, nr 5, s. 3.

4 J.I. Kraszewski, Wieczory wołyńskie, Lwów 1859, s. 144.

5 I. Węgrzyn, Dylematy tradycjonalisty - wątpliwości reformatora - samotność twórcy. „Wieczory wołyńskie” Józefa Ignacego Kraszewskiego, „Wiek XIX. Rocznik Towarzystwa Literackiego im. Adama Mickiewicza" 2012, nr 1, s. 338.
} 
Lud w ogóle przedstawia nam klasę, od wieków w jednym i nie poruszonym trwającą bycie. Gdy inne podeszły z postępem i noszą na sobie piętna tych wieków, w których najsilniej się kształciły, wieśniak nasz pozostał pół-poganinem, tylko co jeszcze ochrzczonym. [...] jest dla nas fenomenem tym ciekawszym, że w nim mamy żywą próbę tego czym cały kraj był w VIII i IX wieku [...]. Obok przyjętej nowej wiary przewiekowały tu przesądy i zabobony pogańskie, zasady, przysłowia, pieśni, obrzędy ${ }^{6}$.

Podobna metaforyka, za której użyciem stoi przekonanie o pierwotności i barbarzyńskości tym razem poleskiej, a nie wołyńskiej ludności, którą trzeba cywilizować, ucząc najbardziej podstawowych i niezbędnych do życia umiejętności, obecna jest w refleksji na temat szkoły i jej misji wygłoszonej w połowie lat dwudziestych XX wieku.

Marian Sydow, poleski referent oświatowy, w 1926 roku pisał:

Na Polesiu mamy tyle zaległości w pracy na wszystkich polach, że szkoła w tych warunkach, znajdując się w rękach ludzi ożywionych zapałem twórczym i odpowiednio przygotowanych do pracy kulturalnej, może odegrać podobną rolę pionierską, jaką w średniowieczu odegrały w Europie napółbarbarzyńskiej klasztory cystersów i kartuzów ${ }^{7}$.

Między innymi dlatego rozwój szkolnictwa we wschodnich województwach II Rzeczypospolitej był jednym z priorytetów, jakie przed sobą stawiano. Czytamy np. w publikacji Polskiej Macierzy Szkolnej:

Pierwszym odruchem było dążenie do zorganizowania szkolnictwa polskiego na Wołyniu, zapewnienia młodzieży polskiej, pozbawionej szkoły ojczystej - szkoły własnej, polskiej, owianej duchem patriotyzmu. Dążenie to było spontanicznym, odruchowym, wypływającym z głębokiego przekonania i wiary, pielęgnowanej pieczołowicie i ofiarnie przez ciężki okres stuletni, że podstawą bytu niepodległego jest świadomość narodowa najszerszych mas i, że tym co budzi tę świadomość, jest w pierwszym rzędzie polska szkoła ${ }^{8}$.

O rozwój szkolnictwa dbało przede wszystkim państwo. Sama szkoła jako budynek i jako instytucja państwowa zajmowała ważne miejsce w przewodnikowych czy krajoznawczych opisach wschodnich ziem II Rzeczy-

\footnotetext{
6 J.I. Kraszewski, Wieczory wołyńskie, Biały Dunajec - Ostróg 2015, s. 80.

7 M. Sydow, Nauczyciel jako czynnik kulturalny na wsi, „Dziennik Urzędowy Kuratorium Okręgu Szkolnego Poleskiego" 1927, nr 1-2, s. 91.

8 Polska Macierz Szkolna na Wołyniu, Równe 1938, s. 4.
} 
pospolitej, choćby dlatego, że była jednym z niewielu miejsc we wschodnich województwach, gdzie turysta mógł szukać schronienia. Antonii Ossendowski w książce Huculszczyna. Gorgany i Czarnohora, wydanej w ekskluzywnej serii Cuda Polski, pisząc o Żabie, wymienia szkołę jako jedno z ważniejszych miejsc na mapie tej wsi, mające świadczyć o rozwoju cywilizacyjnym całej Huculszczyzny: „Ponad sześć tysięcy mieszkańców i około 1500 domów! Sąd, poczta i szpitale, nadleśnictwo, hotele, restauracje, schroniska turystyczne, cerkwie i kościół, pensjonaty, muzeum i szkoły; posterunek straży granicznej, firmy drzewne, sklepy, autobusy, dyliżanse i dorożki" ${ }^{9}$. Nawiasem mówiąc, tak samo postępuje, gdy pisze o Polesiu ${ }^{10}$.

Podobny sposób myślenia zaobserwować można we współczesnych rozpoznaniach historycznych, np. w pracy Włodzimierza Mędrzeckiego, wybitego znawcy historii II Rzeczypospolitej:

za największe osiągnięcie $\mathrm{w}$ dorobku państwa polskiego na Wołyniu w okresie międzywojennym uznać należy budowę struktury szkolnej. W stosunkowo niedługim czasie uruchomiono około 2000 państwowych szkół powszechnych, 10 średnich szkół ogólnokształcących oraz kilka szkół zawodowych (najbardziej znaną z nich była Szkoła Geodezyjna i Miernicza w Kowlu) ${ }^{11}$.

Dodajmy, że tworzenie struktury szkolnej musiało być poprzedzone ogromną liczbą uregulowań prawnych związanych nie tylko ze szkolnictwem, a budowę nowych obiektów projektowano zgodnie z wymogami stawianymi przez „nowoczesność”. Trzeba w tym miejscu wspomnieć, że o tych nowoczesnych szkołach na łamach wileńskiego "Słowa” z goryczą pisał autor reportaży z Polesia, które później złożyły się na Bunt rojstów $w^{12}$, Józef Mackiewicz:

różne szkoły „reprezentacyjne”, murowane za tysiące wyduszonych od nędzarzy podatków, żeby jakiś inspektor, czy inny starosta miał się czym przed bezkrytyczną swą władzą pochwalić. Na taką jedną szkołę murowaną i luksusową wypada kilkadziesiąt izb brudnych, dusznych śmierdzących ${ }^{13}$.

Krytyka polityki związanej ze szkolnictwem obecna jest również w reportażu Ksawerego Pruszyńskiego pt. Prawo do Wołynia. Ukraińskiego chłopca, który ukończył miejscową szkołę, reportażysta przedstawia następująco:

\footnotetext{
9 F.A. Ossendowski, Huculszczyzna. Gorgany i Czarnohora, Poznań 1936, s. 94.

10 F.A. Ossendowski, Polesie, Poznań 1935, s. 182-183.

11 W. Mędrzecki, Polacy i ich Wołyń, „Niepodległość i Pamięć” 2008, nr 27, s. 158.

12 J. Mackiewicz, Bunt rojstów, Wilno 1938.

13 Cat [Stanisław Cat-Mackiewicz], Z dżdżystej doli. Wrażenia i wnioski po przysłaniu na konkurs nowel nauczycielskich, "Słowo” 1935, nr 23.
} 
„Młody, rosły pastuch pilnuje swych krów. Pastuch Rodion zwraca na nas swe głęboko osadzone, ociężale patrzące oczy, swój ludzki pysk o czemś faunicznem jakby półludzkiem, półzwierzęcem a urodziwem" ${ }^{14}$.

W przedstawionym przez niego opisie Wołynianina nie jest trudno dostrzec poczucia wyższości kulturowej i cywilizacyjnej, a nawet biologicznej, jaką ma zarówno autor reportażu, jak i przedstawiona w nim Rosa Bailly, "francuska przyjaciółka Polski" - autorka m.in. Histoire de l'amitié franco-polonaisem oraz L'Hommage de la France à Mickiewicz. Takie orientalizujące spojrzenie wydaje się charakterystyczne dla postrzegania mieszkańców krain położonych na wschód od Polski przez Polaków i obywateli innych państw europejskich (nawiasem mówiąc, Polacy w ten sposób bywają również widziani). Było ono obecne nie tylko w cytowanych wyżej Wieczorach wołyńskich, ale i we wcześniejszym Wspomnieniu Wołynia, Polesia i Litwy. Stanisław Cat-Mackiewicz widzi w podobny sposób studiujących w moskiewskim „instytucie ludów Północy” Aleutów, Tunguzów, Jakutów i Samojedów: „Wszystko to byli mali ludkowie, których Zagłoba na pewno zabrałby się uwędzić i w farze Łowickiej jako votum powiesić - żółte, skośnookie, o wargach wydętych, kwadratowych głowach, krzywych nogach"15. I nie jest $\mathrm{w}$ takim spojrzeniu na przebywających w europejskich miastach rosyjskich przedstawicieli ludów północy i Syberii odosobniony.

Konsekwencją objęcia przedstawicieli autochtonicznych ludów przez ZSRR zabiegami edukacyjnymi, zdaniem Mackiewicza, będzie to, że część z tych osób „wróci na północ, do swych jurt i będzie tam apostołami bolszewickiego katechizmu (politgramoty)" ${ }^{16}$. Prezentując postać Rodiona, Pruszyński musi być raczej daleki od myśli, że chłopak po ukończeniu szkoły będzie „apostołem” polskiej myśli narodowej czy choćby państwowej. Antycypuje natomiast ten nurt postkolonialnego dyskursu drugiej połowy dwudziestego wieku, w którego centrum znajduje się analiza relacji zachodzących między Prosperem i Kalibanem - postaciami dramatu Szekspira pt. Burza ${ }^{17}$. Ważnym jej wątkiem jest scena, w której Kaliban odpowiada Prosperowi, zarzucającemu mu niewdzięczność:

\footnotetext{
14 K. Pruszyński, Prawo do Wołynia, „Wiadomości Literackie” 1936, nr 43, s. 3.

15 S. Cat-Mackiewicz, Myśl w obcęgach. Studia nad psychologia społeczeństwa Sowietów, Warszawa 1931, s. 25-26.

16 Tamże, s. 26.

17 Zob. K. Cholewińska, Wszyscy jesteśmy Kalibanami: (post)kolonialne wizje latynoamerykańskiego podporzadkowania, „Annales Universitas Marie Curie-Skłodowska” 2015, nr 1.
} 
Mowę mi dałeś; cała z tego korzyść,

Że kląć dziś mogę; niech za to na ciebie

Zaraza padnie, że mi dałeś mowę! ${ }^{18}$

Główną korzyścią osiągniętą przez Kalibana, wynikającą z procesu edukacyjnego, którym objął go Prospero, jest przede wszystkim umiejętność dostrzeżenia krzywd doznanych od swojego nauczyciela i zdolność złorzeczenia na swój los - los „wyedukowanego", ale zniewolonego prawowitego właściciela ziemi, na której chwilowo i przez przypadek znajduje się Prospero.

Taka postawa nie jest odosobniona. Roberto Fernández Retamar, kubański intelektualista, poeta i eseista widzi w Kalibanie symbol całego narodu kubańskiego: „Naszym symbolem jest [...] Kaliban. Prosper [...] wybił naszych przodków, Kalibana pojmał w niewolę i nauczył go swego języka, by móc się z nim porozumieć: cóż innego może uczynić Kaliban, niż użyć tego właśnie języka - innego dziś nie posiada - aby go przeklinać [...]"19.

W refleksji Ksawerego Pruszyńskiego na temat Wołynia dostrzec można niekonsekwencję. W Prawie do Wołynia pisarz domaga się podmiotowości zarówno dla Wołynia jak i jego mieszkańców, natomiast w innym reportażu, opublikowanym dwa lata później i zatytułowanym Byt to niegdyś kraj bogaty, stwierdza: „Niełatwo przyszło łacińskości, polskości i Zachodowi zdobyć ten kraj" 20 .

Właśnie tę niekonsekwencję dobrze uosabia postać Rodiona. Chłopak najpierw nieudolnie recytuje jedną z bajek La Fontaine, a potem stwierdza: „,- A teper to i na korowu po francusku kłyczu...". Pruszyński słyszy w tej wypowiedzi sarkazm. Wypowiedź Rodiona dotyczy szkoły. „Pastuch chciał, żebym ocenił jak głęboko pozwoliła mu posiąść mowę Ludwika XIV i Moljera, oraz jak wspaniałe nowe horyzonty otworzyła mu przed oczami" ${ }^{21}$.

Słowa Rodiona (Rodiona-Kalibana?) stają się dla Pruszyńskiego pretekstem do wygłoszenia krytycznych refleksji. Twierdzi reportażysta, że włączanie Wołynia i innych wschodnich ziem polskich, a raczej jej młodych obywateli w obręb państwa polskiego, musi się odbywać inaczej niż według modelu edukacyjno-wychowawczego, którego fundamentem jest przekonanie o polskim prawie do Wołynia wynikającym z dawnych związków kulturalnych.

\footnotetext{
18 W. Shakespeare, Burza, przeł. L. Urlich, w: tegoż, Dzieła dramatyczne Williama Shakespeare'a $w$ dwunastu tomach, t. 11, Kraków 1985, s. 24.

19 R.F. Retamar, Kaliban, w: tegoż, Kaliban i inne eseje, przeł. H. Czarnocka, Kraków 1983, s. 13.

${ }^{20}$ K. Pruszyński, Byt to niegdyś kraj bogaty, s. 3.

21 K. Pruszyński, Prawo do Wołynia, s. 3.
} 


\section{III}

Problematykę związaną z edukacją rozpatrywać najłatwiej na osi państwo - szkoła - uczeń. Przy czym szkoła pełni funkcję ekspozytury państwa, prowadzi działalność nie tylko oświatową i wychowawczą, ale także propagandową i informacyjną. W takim oglądzie łatwo pominąć jednak bardzo ważny, a kto wie, czy nie najważniejszy, bo pośredniczący „element" w relacji pomiędzy państwem, szkołą, a młodym obywatelem - nauczyciela.

Nauczyciel, jak można sądzić - nie tylko w dwudziestoleciu międzywojennym i nie tylko we wschodnich województwach Polski - miał obowiązek uczestnictwa $\mathrm{w}$ wielu dodatkowych formach aktywności szkolnej i pozaszkolnej, których charakter był jawnie propagandowy. Większość musiał sam organizować, a do uczestnictwa w nich nakłaniani byli nie tylko uczniowie, ale również wszyscy inni członkowie lokalnej społeczności.

Ilustruje to np. rozesłany przez kuratora wołyńskiego, Wincentego Sikorę, harmonogram obchodów rocznicy uchwalenia Konstytucji 3 maja, które w roku 1926 na Wołyniu miały się rozpocząć już dzień wcześniej „o zachodzie słońca" 22 . Wówczas

orkiestra miejscowa, winna [...] przejść ulice wioski lub miasteczka, grając pieśni narodowe [...]. Dobrze jest otoczyć orkiestrę czworobokiem dziatwy szkolnej, trzymającej w rękach lampiony oraz kilkoma osobami starszymi z pochodniami [...]. Takie przejście orkiestry zawiadamia ludność o nadchodzącym święcie państwowym. Komitet [organizacyjny - Z.K.] winien dołożyć starań, aby na dzień następny ludność ozdobiła wszystkie chaty flagami o barwach państwowych. W wioskach, w których nie ma orkiestry, można przeprowadzić ulicami dziatwę klas wyższych i śpiewać pieśni narodowe. Zrobi to dobre wrażenie na rodzicach i rodzinach dziatwy

- zaleca kurator. Trzeciego maja orkiestra powinna zagrać „przed szkołą ozdobioną flagami, zielenią i kwieciem”. Będzie to sygnałem „zbiórki dla całej ludności" ${ }^{23}$. Potem: uroczystości w kościołach i cerkwiach, zbiórka w szkole lub największej sali wsi lub miasteczka, odśpiewanie hymnu, „przemówienie jednego z członków Komitetu, kilka okolicznościowych deklamacji i chór" 24. Po południu miała odbyć się „zabawa” mająca trzy odsłony: dla dzieci, dla młodzieży i dla dorosłych.

Godna uwagi jest wielotorowość, z jaką nauczyciele mieli realizować propaństwowe cele. Np. z okazji 10-lecia odzyskania dostępu do morza ku-

22 W. Sikora, W sprawie obchodów rocznicy Konstytucji 3 maja 1926 r., „Dziennik Urzędowy Kuratorium Okręgu Szkolnego Wołyńskiego" 1926, nr 3.

23 Tamże, s. 66.

24 Tamże, s. 67. 
ratoria zalecały organizacje wycieczek szkolnych do Gdyni (której koszty mieliby pokrywać uczniowie), a niemal $\mathrm{w}$ tym samym czasie $\mathrm{w}$ poleskim dzienniku kuratoryjnym pojawia się konspekt lekcji ${ }^{25}$, której podstawowym celem jest takie jej poprowadzenie, by od uczniów wyszła inicjatywa zapisania "szkoły na członka Oddziału Ligii Morskiej i Rzecznej w Brześciu”, co ostatecznie skutkować miało płaceniem składek. Autor konspektu dokonuje nawet wstępnej kalkulacji:

jeden uczeń wpłaci rocznie 12 groszy. W całej Polsce uczęszcza do szkół przeszło 3.500.000 uczniów. Jeżeli wszyscy będą członkami Ligi, otrzymamy kwotę 420,000 zł, rocznie. Zapytamy [...] co można za tę sumę wybudować w porcie gdyńskim, albo ile kosztuje budowa okrętu handlowego, gdyż w ciągu 7 lat uczęszczania do szkoły, wpłaci każdy uczeń 84 gr., co mnożąc przez liczbę uczniów w Polsce wyniesie 2,940.000 zł., a za tę sumę można by kupić może i okręt ${ }^{26}$.

Przywołanie trzeciomajowch atrakcji i konspektu lekcji poświęconej Lidze Morskiej i Rzecznej było tu istotne ze względu na to, że są one ogromnie ważnym dokumentem wychowania państwowego młodzieży uczęszczającej do szkół we wschodnich województwach Polski lat dwudziestych i trzydziestych. Stanowią jednak małą cząstkę zadań, które powierzano nauczycielom. To ich silami organizowane były w szkołach liczne kwesty, podczas których zbierano pieniądze (często wśród najbiedniejszej grupy ludności, np. ukraińskich i poleskich dzieci) m.in. na budowę szkól, rozwój oświaty za granicą, budowę pomników, a nawet na samolot, w którym polska lotniczka miała wziąć udział $\mathrm{w}$ challengu; przeprowadzano akcje walki $\mathrm{z}$ analfabetyzmem wśród dorosłych i wszawicą oraz alkoholizmem wśród dzieci; zwalczano chrabąszcza majowego i oset, zakładano ogródki szkolne, zalesiano i zadrzewiano, przeprowadzano pogadanki na temat szkodliwości niszczenia przez młodzież szkolną infrastruktury telefonicznej i telegraficznej, a także o tym, że nie należy w turystów rzucać kamieniami i błotem. A pamiętać trzeba, że w szkołach obchodzono nie tylko rocznicę uchwalenia Konstytucji 3 maja. Ważnymi wydarzeniami były inne uroczystości państwowe mające charakter cykliczny, jak np. imienny Marszałka Józefa Piłsudskiego, co stwarzało okazję, by, chcąc nie chcąc, zachęcać uczniów do pisania okolicznościowych wierszy. Cytuje je w swoim artykule Czesław Zaleski ${ }^{27}$ :

\footnotetext{
25 Szer-Szeń, Liga Morska i Rzeczna, „Dziennik Urzędowy Kuratorium Okręgu Szkolnego Poleskiego" 1929, nr 5, s. 246-247.

26 Tamże, s 247.

27 Cz. Zaleski, Józef Piłsudski w pieśni starszego pokolenia i młodzieży. „Dziennik Urzędowy Kuratorium Okręgu Szkolnego Wołyńskiego" 1932, nr 3. Cytowane utwory znajdują się w przywołanym artykule na s. 100-102.
} 


\section{Na straży}

Na straży naszej, polskiej szkoły Wystrzela w górę pomnik chwały.

Na szczycie jego srebrno-pióry,

Co zda się lecieć, hen, pod chmury.

A pod nim postać dobrze znana

Dla wszystkich droga, ukochana:

To nasz Marszałek, Wódz Naczelny, Jako dąb twardy, mądry, dzielny.

O cześć Ci, Wodzu, cześć i chwała Za to, że Polska zmartwychwstała, Żeś zgasił pożar wschodnich granic!

- Zakusy katów poszły na nic.

Na straży stoisz naszej szkoły, Wystrzelasz w górę pełen chwały.

Nad Tobą orzeł srebrno-pióry,

Co zda się lecieć hen do góry.

Władysław Hołubik uczeń VI oddz. publ. szk. powsz. w Kowlu

\section{W dniu Imienin Marszałka Piłsudskiego}

W dniu Twych Imienin,

Gdy Polska cała

Składa Ci szczere życzenia -

Życzy też szczęścia Irka mała.

Gdzie słońce tylko

Świeci na niebie -

Myśli Polaków

Dążą do Ciebie.

Myśląc z wdzięcznością

O tym, co wsławił

Imię swe wiecznie

I Polskę zbawił.

Irena Wierzbowska uczennica klasy II-giej, gimn. państw, we Włodzimierzu

Władze oświatowe oczekiwały ogromnego zaangażowania nauczycieli i całkowicie sankcjonowały fakt, że większość (jeśli nie wszystkie) z nakładanych nań obowiązków będą wykonywali za darmo. Bodaj najlepiej myśl tę wyraża kurator wołyński Karol Kostro, gdy zwraca się do podwładnych: „niechaj nagrodą Wam będzie za trudy poniesione wdzięczność wszystkich tych, których umysły i dusze oświecać będziecie, odkrywać nowe prawdy 
i do lepszej przyszłości sposobić" 28 . Kostro nie był w takim myśleniu odosobniony. Jego poprzednik, kurator Sikora, miał podobne poglądy: „Przekonany jestem, że nauczycielstwo, pomne swych zadań oświatowych i kulturalnych na nim ciążących, z całą energią i znanym zapałem weźmie się do jak najlepszego zorganizowania obchodu rocznicy 3 Maja" - pisał o rocznicy, o której była już mowa. Równocześnie prosił o sprawozdanie z ich pracy: „Sprawozdania z obchodów nadeślą Kierownicy szkół Panom Inspektorom najdalej do dnia 31 maja 1926 r." 29.

Odpowiedź na pytanie, czy nauczyciele byli zadowoleni ze swojej pracy i czy z entuzjazmem wykonywali powierzane im dodatkowe obowiązki, nie jest łatwa i zależy od tego, gdzie będziemy jej szukali.

Odpowiedzi pozytywnej udzieliłaby Halina Olmieńska, tytułowa bohaterka przeznaczonej dla szerszego grona czytelników niewolnej od propaństwowej propagandy powieści Antoniego Ossendowskiego pt. Nauczycielka z 1935 roku ${ }^{30}$, której akcja rozgrywa się na Polesiu. Jakkolwiek pisarz próbował przedstawić społeczne i przyrodnicze realia regionu, w którym umieścił akcję swojej książki, a w potocznym przeświadczeniu mógł uchodzić za znawcę Polesia, to jego kompetencjom nie należy ufać. Zwraca na to uwage przy innej okazji Józef Obrębski ${ }^{31}$.

Dziewczyna ma „skomplikowane” życie emocjonalne, jak na bohaterkę powieści popularnej przystało, ale odczuwa prawdziwą satysfakcję ze swojej nauczycielskiej misji i zapał do jej pełnienia. Ossendowski, którego biegnąca wieloma torami twórczość pisarska nie jest wolna od propaństwowej propagandy, konstruuje tę postać w taki sposób, jakby była ona wierną i uważną czytelniczką kuratoryjnych zaleceń i apeli ${ }^{32}$.

Warto $\mathrm{w}$ tym miejscu wspomnieć o tym, w jaki sposób Olmieńska broni się przed zarzutami, w myśl których jej nauczycielska działalność polega na polonizacji mieszkańców Polesia: „Was [...] nie chcę przerobić na Polaków, bo nie jesteście Polakami. [...] Ale i z was chciałabym uczynić obywateli, którzy by państwu swemu dopomagali, bronili i poważali..." [N, s. 94]. A jej wypowiedź można potraktować jak tłumaczenie działalności całego polskiego szkolnictwa we wschodnich województwach. Nawiasem mówiąc,

\footnotetext{
28 Kurator Okręgu Szkolnego, K. Kostro, Do ogótu nauczycielstwa wołyńskiego, „Dziennik Urzędowy Kuratorium Okręgu Szkolnego Wołyńskiego" 1926, nr 10, s. 1.

29 W. Sikora, W sprawie obchodów rocznicy Konstytucji 3 maja 1926 r., s. 67.

30 F.A. Ossendowski, Nauczycielka. Powieść, Poznań 1935.

31 J. Obrębski, Polesie, red. nauk. i wstęp A. Engelking, Warszawa 2007, t. 1, s. 441.

32 Zob. Z. Kopeć, Kobieta na bagnach, w: tegoż, W cieniu historii. Dwudziestowieczne doświadczenia i narracje, Poznań 2018.
} 
optymizmu bohaterki Ossendowskiego nie podziela np. nauczycielka z debiutanckiego utworu Leopolda Buczkowskiego pt. Wertepy z drugiej połowy lat trzydziestych. Żyjąca na pograniczu Wołynia i Podola bohaterka widzi zarówno nędzę mieszkańców wsi, w której żyje, jak i swoją własną ${ }^{33}$.

Satysfakcję z pełnienia nauczycielskiej misji odczuwa również Jadwiga Siedlecka - autorka (i chyba bohaterka) pracy nadesłanej na konkurs zatytułowany "Dziecko poleskie" ${ }^{34}$. Konkurs ten poleskie kuratorium ogłosiło na początku 1929 roku, „pragnąc pobudzić myśl i sumienia nauczyciela wychowawcy". W ogłoszeniu znalazły się szczegółowo przedstawione oczekiwania ${ }^{35}$. Rozprawy „uznane za najlepsze" miały być drukowane w „Dzienniku Urzędowym" oraz nagrodzone. Kwoty przewidziane jako pierwsza i druga nagroda (250 i 150 zł) stanowiły solidną zachętę ${ }^{36}$. W 7 numerze „Dziennika” ukazał się jeden z konkursowych utworów, który wydrukowano bez jakiegokolwiek komentarza, nie informując ani które miejsce zajął, ani czy i kiedy wydrukowane będą kolejne ${ }^{37}$.

Autorka opublikowanej pracy poważnie potraktowała zalecenia konkursowe, z entuzjazmem opisując swoje dydaktyczne i wychowawcze problemy. Oczywiście, wszystkie rozwiązuje koncertowo i z każdej opresji wychodzi zwycięsko. Znajduje (dzięki radzie „doświadczonego pedagoga”) sposób, by nauczyć białoruskiego chłopca czytania po polsku, odbiera szczęśliwie poród jednej z chłopek, przeżywa mocno fakt, że na wsi doszło do podpalenia, o co oskarżony był ojciec jednego ze uczniów, martwi się nędznymi warunkami życia niektórych swoich podopiecznych i cieszy się, kiedy jeden z klasowych rozrabiaków broni dziewczynki, z której koleżanki śmieją się, że ścięła włosy: „- Dziwne, dziwne! - mówi - To lepiej się kołtuna

${ }^{33}$ Kobieta „dokładnie zdawała sobie sprawę z nędzy swego istnienia, ale równocześnie świadoma była, że dokoła niej nie dzieje się lepiej, że życie jej w tym opuszczeniu musi przepłynąć tak, jak przepływa innym" [L. Buczkowski, Wertepy, Kraków 1973, s. 40].

34 „Dziennik Urzędowy Kuratorium Okręgu Szkolnego Poleskiego” 1929, nr 1, s. 25-26.

35 „winny być uwzględnione wpływy środowiska - moment etnograficzny, stan zdrowotny i rozwój fizyczny badanej dziatwy szkolnej i podana charakterystyka psychologicznych właściwości dziecka, oparta o spostrzeżenia nad wyobraźnią, cechami inteligencji, właściwościami myślenia, życiem uczuciowym, objawami temperamentu, wolą etc."

„Autor winien zastanowić się nad zainteresowaniami uczniów, ich uspołecznieniem, wreszcie podać zabiegi pedagogiczne przez siebie stosowane i ich wynik, podać charakterystykę dziecka indywidualną i dziecka traktowanego jako członka zbiorowości".

36 Według danych „Głosu Porannego" z 15 XII 1929 roku (nr 312) nauczyciel szkół powszechnych na prowincji zarabiał 367,14 zł miesięcznie. Artykuł nosił tytuł: Ile zarabiaja urzędnicy. Premier - minister - wojewoda - starosta.

37 Dziecko poleskie. Przez Jadwige Siedleckg (Konkurs Kuratorium Okregu Szkolnego Poleskiego), „Dziennik Urzędowy Kuratorium Okręgu Szkolnego Poleskiego” 1928, nr 7. 
we włosach doczekać, niż mieć czystą głowę? Przecie to zdrowo mieć włosy ostrzyżone" ${ }^{\prime \prime 3}$.

Opis tej scenki nieprzypadkowo znajduje się na końcu utworu. Reakcja chłopca wystawia jak najlepsze świadectwo zdolnościom wychowawczym nauczycieli. Wszak kołtun jest jednym z objawów charakterystycznej dla Poleszuków "choroby", o czym już wcześniej pisał Kraszewski w swoim Wspomnieniu Polesia, Wołynia i Litwy. W utworze Siedleckiej nie sposób znaleźć jakiekolwiek uwagi krytycznej odnoszącej się czy to do sposobu funkcjonowania szkół, czy do nadmiernych oczekiwań stawianych pracującym w nim nauczycielom.

Zupełnie inaczej rzecz przedstawia się $\mathrm{w}$ przypadku nowelek nadesłanych na konkurs ogłoszony w 1935 roku przez wychodzące w Wilnie "Słowo", bo i chyba "Słowo" ogłaszało swój konkurs w zupełnie innym celu niż poleskie kuratorium. Fakt jego rozstrzygnięcia odnotował nawet wychodzący w Warszawie zorientowany prawicowo dziennik „ABC Nowiny Codzienne":

Niemal wszystkie utwory nadesłane na konkurs [...] pełne są pesymizmu, nieufności do przełożonych, nienawiści do inspektorów, nienawiści do samego życia, obrzydzonego pracą żmudną, nieraz bezcelową, a nigdy nie mogącą liczyć na nagrodę, czy uznanie. Cóż bowiem znaczy dla ginącej na gruźlicę nauczycielki $\mathrm{w}$ błotach poleskich, że na trybunie sejmowej minister będzie nazywał nauczycielstwo przednią strażą Rzeczypospolitej [... ${ }^{39}$

- prezentuje swoje refleksje publicysta „ABC...” i w gruncie rzeczy wcale nie przedstawia $w$ nich obrazu życia i pracy nauczyciela wyłaniającego się z konkursowych utworów w czarniejszych barwach niż te, którymi zostały sporządzone. Redaktor "Słowa” - Stanisław Cat-Mackiewicz pisał o nadesłanych na konkurs utworach, że:

mówią o szalonej sprzeczności pomiędzy robotą papierową a rzeczywistością. W papierach pisze się o skoczniach, świętach lasu, świętach pieśni, dziesiątkach organizacji, o szerzeniu najwspanialszych i najidealistyczniejszych pomysłów, a $\mathrm{w}$ rzeczywistości nauczyciele mają do czynienia z wszami, brudem, ciemnotą, głodem, kromkami chleba przyniesionymi w śmierdzących nędzarskich torbach ${ }^{40}$.

\footnotetext{
38 Tamże, s. 318.

39 [brak autora], Gehenna inteligenta na Kresach Wschodnich. "Nie trzeba nawuki”. Co odstaniaja reportaże z życia szkoty powszechnej, „ABC Nowiny Codzienne” 1935, nr 46.

40 Cat [Stanisław Cat-Mackiewicz], Z dżdżystej doli. Wrażenia i wnioski po przysłaniu na konkurs nowel nauczycielskich, „Słowo” 1935, nr 23.
} 
Właśnie na tę papierową rzeczywistość, o której pisze Cat-Mackiewicz, składają się wspomniane już wcześniej obchody świąt i uroczystości szkolnych oraz zbiórki pieniędzy. Autor Buntu rojstów wspomina, że „towarzyszyły mu rumieńce wstydu i zażenowania", gdy czytał, jak jedna z nauczycielek „musiała z chłopów ściągać po pięć groszy na ozdóbki choinkowe, a chłopi tych pieniędzy nie mieli". Zauważa, że zarobki nauczycieli są tak niskie, iż ich dzieci są "głodne, bez obuwia, bez nauki, bez przyszłości. Chorują [...], dostają gorączki, umierają bez opieki, w ciężkich warunkach higienicznych". Być może $\mathrm{z}$ tego powodu jedna $\mathrm{z}$ autorek określa siebie i innych, którzy zgodzili się pełnić nauczycielski trud, mianem „trzeciej płci”, czyli ludzi, którzy absolutnie nie powinni mieć własnych dzieci ${ }^{41}$. Tyle, że nie tylko problemy materialne stały nauczycielom na przeszkodzie w założeniu rodziny, ale również liczne nakładane na nich dodatkowe obowiązki (o niektórych już była mowa), które czyniły z nich „Mańkę do wszystkiego”, jak określa to autor najwyżej nagrodzonej pracy pt. Zostałem nauczycielem ${ }^{42}$.

Tej rozpaczliwej wizji nauczycielskiego losu nie można zamienić na lepszą, chyba że na utopijną (rajską?), jak czyni Jerzy Wyszomirski, co samo w sobie daje wyobrażenie o pracy nauczyciela ${ }^{43}$.

Trudno się zatem dziwić, że Rodion z reportażu Pruszyńskiego uczony w polskiej szkole przez prawdopodobnie zmęczonych i sfrustrowanych nauczycieli odpowiada reportażyście $w$ taki sposób, że ten jego wypowiedź, być może przeceniając nadmiernie swojego rozmówcę, bierze - powtórzmy - za "podstępne chłopskie szyderstwo" ${ }^{44}$. Trudno też się dziwić Pruszyńskiemu, że patrząc na Rodiona, pozwala sobie na następującą refleksję: „Jak młody żebrak-kaleka, obwieszony medalami wojskowymi, jest odstraszającą pozostałością wojny, tak ci wszyscy młodzi, zdrowi i okaleczeni ludzie są chodzącymi karykaturami oświaty" 45 .

41 [Godło: Rzeczywistość], Bojowniczka przyszłości, „Słowo” 1935, nr 35, s. 3.

42 R. Tumski [pseudonim], Zostałem nauczycielem, "Słowo” 1935, nr 32.

43 "Co się tyczy nauczycieli, wytłumaczyłby im, że są, ściśle biorąc, tylko nauczycielami. Uczyć od ósmej do drugiej, a potem frei. Żadnych świetlic, strzelców, kół i organizacji, oświaty pozaszkolnej, straży przednich, kulturtregierstwa i społecznikostwa. O godzinie drugiej obiad, krótkie dolce for ninte, godzina na poprawienie zeszytów, druga na przygotowanie do lekcji, spacer, radio, poczytać książki i gazety, pogadać z sąsiadem, poplotkować, o dziesiątej do łóżka, spać osiem godzin. Wstawać o szóstej z rana, trochę gimnastyki, i do pracy. Niedziela do całkowitego rozporządzenia" [J. Wyszomirski, Nad lektura nowel konkursowych, „Słowo" 1935, nr 29].

44 Zob. H. Gosk, Polski dyskurs kresowy w niefikcjonalnych zapisach międzywojennych. Próba lektury w perspektywie postcolonial studies, "Teksty Drugie" 2008, nr 6.

45 K. Pruszyński, Prawo do Wotynia, s. 3. 
Nie sposób odmówić porównaniu Pruszyńskiego siły rażenia, ale w rzeczywistości sprawa jest chyba bardziej skomplikowana. Trzeba podkreślić, że do szkól, w których uczyli autorzy prac konkursowych i do szkoły, którą ukończył Rodion, chodzili również (a często przede wszystkim) uczniowie narodowości białoruskiej i ukraińskiej. Dla nich język polski nie był językiem ojczystym, a udział w polskich świętach narodowych lub ich rocznicach nie był czymś atrakcyjnym. Karol Sanojca, autor bardzo ważnej i trudnej do przecenienia pracy poświęconej relacjom polsko-ukraińskim w szkolnictwie państwowym południowo-wschodnich województw Polski, odnotowuje przypadki bojkotu organizowanych $\mathrm{w}$ szkołach zbiórek pieniężnych i zauważa, że niechęć młodzieży ukraińskiej do obchodów polskich „,́́wiąt narodowych rozciągała się także na tradycje i symbole polskiej państwowości" ${ }^{46}$. To wszystko z pewnością nie ułatwiało pracy nauczycielom. Nauczycielom - Polakom, których była przeważająca większość. Nauczyciele ukraińscy byli w dużo gorszej sytuacji - groziło im, że będą posądzani o antypolską agitację ${ }^{47}$.

Nawiasem mówiąc, zupełnie inną kwestią, o której trzeba choćby wspomnieć, były programy nauczania, zwłaszcza historii i języka polskiego w szkołach średnich. Trudno było uczyć w ukraińskiej czy poleskiej szkole, gdzie na lekcjach historii i języka polskiego prezentowany jest wyłącznie polski punkt widzenia. Sądzić można, że dla ukraińskiej młodzieży szkolnej niełatwa do zaakceptowania była np. powieść Ogniem i mieczem, która dopiero w 1935 roku przestała być lekturą obowiązkową. Być może na usunięcie tego utworu ze spisu lektur wpływ miał szereg wypowiedzi podważających zasadność jego obecności w szkołach, do których chodziła ukraińska młodzież. Artykuł Józefa Grodeckiego z 1931 roku potraktować można jako jeden z przykładów:

Ileż to jeszcze czasu krwawy nacjonalizm polski i ruski i obrazy walk bratobójczych z Ogniem i mieczem będą w samym zaraniu rozwoju zatruwać dusze młodzieży narodu, powołanego do wielkich przeznaczeń? Czyż i gimnazja Małopolski Wschodniej rozbudzają dziś w tamtejszych Rusinach miłość i wierność dla Polski na materiale Ogniem i mieczem? Czy nie tej to „lekturze” w IV klasie zawdzięczamy i UNDO i UOW, i akty sabotażu, i zamachy na dostojników państwowych ${ }^{48}$.

46 K. Sanojca, Relacje polsko-ukraińskie w szkolnictwie państwowym południowo-wschodnich województw Drugiej Rzeczypospolitej, Kraków 2013, s. 220.

47 Tamże, s. 321-327.

48 J. Grodecki, Program nauczania języka polskiego w szkole średniej. Metody i wyniki, w: Teoria ksztatcenia literackiego w latach 1918-1939. Antologia, cz. 1, red. L. Jazownik, Zielona Góra 2001, s. 201. Pierwodruk: J. Grodecki, Program nauczania języka polskiego w szkole średniej. Metody i wyniki. „Polonista” 1931, z. 3. 
We wspomnieniu z roku 1942 roku Pruszyński przywołuje Wołyń, wpisując swoją opowieść w zmitologizowany arkadyjski dyskurs, który dekonstruuje Daniel Beauvois ${ }^{49}$. Ale przekonanie, że świat jego dzieciństwa się już skończył w Prawie do Wołynia widoczne jest bardzo wyraźnie. Ciekawe i zastanawiające jest to, że Pruszyński jedynie w Wołyniu współczesnym, a nie w "dawnym” widział stosunki kolonialne („Czy kto widział sznury pociągów wywożące stąd kaolin, glinkę porcelanową, do obcych, dalekich wytworni jak z kolonii wywozi się surowce do uprzemysłowionych metropolii? I pomyśleć, że jednak nie zawsze ten kraj był kolonią?" 50 - pyta). Mimo to te antykolonialne wątki dotyczące współczesności Wołynia pozwalają zestawić niektóre jego reportaże z Buntem rojstów Mackiewicza.

Być może dlatego w centrum jego zainteresowań jest moment, w którym znalazła się ludność Wołynia, a zwłaszcza niektórzy jej przedstawiciele mieszkający w okolicach Dermania, gdzie - wynika z reportażu - dokonano komasacji gruntu. Dzięki komasacjom wieś wołyńska przechodzi ogromną metamorfozę:

Cała wieś Rodiona - pisze Pruszyński - została rozbita w puch, rozpylona po wzgórzach, rozrzucona po stepie. Można powiedzieć, że nie ma tej wsi, i rzeczywiście takiej jak była, już nie ma. Stłoczone w gęstwę chaty wielkiej wsi ruskiej, narażonej co roku na pożary i epidemie, rozsunęły się na strony dzięki komasacji ${ }^{1}$.

Pruszyński rozumuje następująco: zmiana układów społecznych powinna za sobą pociągnąć choćby minimalną zmianę ustroju szkolnego. Do nowej wsi wołyńskiej - twierdzi - przyjść powinien nauczyciel, który pokazałby chłopu nie ,jjak czytać, ale co czytać i jakie z tego czytania może wyciągnąć korzyści" 52 .

Nieprzypadkowo przywołuje Pruszyński Dermań. Właśnie stamtąd pochodzą bohaterowie bardzo wysoko cenionej przez niego powieści Ułasa Samczuka pt. Wołyń, której pierwszy tom wydano w Polsce w 1938 roku ${ }^{53}$,

49 D. Beauvois, Trójkąt ukraiński. Szlachta, carat i lud na Wotyniu, Podolu i Kijowszczyźnie 1793-1914, przeł. K. Rutkowski, Lublin 2005; zob. też B. Bakuła, Kolonialne i postkolonialne aspekty polskiego dyskursu krajoznawczego, „Teksty Drugie” 2006, nr 6.

50 K. Pruszyński, Wspomnienia, reportaże, artykuty, t. 1, s. 221.

51 K. Pruszyński, Prawo do Wotynia, s. 3.

52 Tamże.

53 U. Samczuk, Wołyń, przeł. T. Hollender, Warszawa 1938. 
a do której sam napisał przedmowę ${ }^{54}$. Pisze Pruszyński, że utwór ma dwóch bohaterów: dziecko chłopskie i masę chłopską ${ }^{55}$. Można jego stwierdzenie skorygować, widząc jednego z głównych bohaterów powieści w chłopie Matwieju, drugiego w jego synu Wołodce. Pierwszego cechował głód ziemi Matwiej był w stanie zrobić bardzo dużo, by zdobyć więcej ziemi, na której mógłby pracować i dzięki której mógłby godnie żyć - gotów był nawet szukać jej na Syberii ${ }^{56}$. Drugiego z bohaterów - Wołodkę, o którym mówią „Maleńki on, ale ważnienki" 57 - cechował głód wiedzy. Uzdolnione chłopskie dziecko zrobiłoby wiele, by jak najszybciej wiedzieć jak najwięcej. Problematyka Wotynia Samczuka i sposób konstrukcji świata przedstawionego tego utworu pozwala widzieć tę powieść jako zjawisko literackie paralelne do utworów współtworzących w Polsce lat trzydziestych tzw. nurt chłopski. Nawiasem mówiąc, los bohatera jednego z nich - Spowiedzi Józefa Mortona (1937) - pokazuje, że ukończenie szkoły przez chłopskiego syna wcale nie przynosi mu odmiany losu i wcale nie czyni go szczęśliwszym. Przeciwnie, skazuje go na wykorzenienie i bezrobocie.

Pruszyński „musiał podróżować, aby pisać, podróż była nie tylko przywilejem, ale rodzajem zniewolenia" - pisze Marta Wyka ${ }^{58}$. „W penetrowaniu spraw obcych nie ćmiły mu ostrości dziennikarskiego spojrzenia warstwy tradycji, a ostrość dziennikarskiego języka nie hamował obowiązek "państwotwórczy»" - zauważa Zygmunt Ziątek ${ }^{59}$. Pruszyński opisując postać Rodiona, obnażał stan polskiego szkolnictwa. Podróże, np. do Niemiec i Danii pozwoliły mu zauważyć nowe formy wiejskiej przedsiębiorczości, obecne $w$ tych krajach - kooperatywy, czyli spółdzielnie. „Chłop duński rozpoczął od komasacji, na komasacji nie skończył, przeszedł do spółdzielni, do własnych szkół, które czynią rozróżnienia językowe między mową duńską z Zelandji a tą samą mową duńską w Jutlandji" 60 - stwierdza, wskazując na wysoki poziom nauczania $\mathrm{w}$ duńskich szkołach. Reportażysta nie przez przypadek przywołuje duński sposób gospodarowania i jego wpływ na rozwój szkolnictwa. Na podobną korelację $\mathrm{w}$ tym samym czasie zwracał uwagę również Antoni Piątkowski: „Przez spółdzielczość, przy wysokim poziomie oświaty

\footnotetext{
54 K. Pruszyński, Pomyśl o Wołyniu, w: U. Samczuk, Wołyń, s. 5-9.

55 K. Pruszyński, Prawo do Wotynia, s. 3.

56 U. Samczuk, Wotyń, s. 29.

57 Tamże, s. 77.

58 M. Wyka, Pisarstwo Ksawerego Pruszyńskiego. Biograficzność, gatunkowość, teorie recepcji, w: Zagadkowy Ksawery Pruszyński, red. B. Gautier, M. Urbanowski, Kraków 2019, s. 109.

59 Z. Ziątek, Ksawery Pruszyński, Warszawa 1972, s. 48.

60 K. Pruszyński, Prawo do Wotynia, s. 3.
} 
chłop duński osiągnął kulturalne warunki życia i nieporównywalny z naszym dobrobyt" ${ }^{\prime \prime}$. Tyle, że by widzieć dobrze działającą spółdzielnię, nie trzeba był jechać aż do Danii. W wielkopolskim Liskowie od 1924 roku działała spółdzielnia „skupiająca: mleczarnię, piekarnię, Stowarzyszenie Zbożowe oraz Stowarzyszenie Budowlane" ${ }^{62}$. Nawiasem mówiąc, idea spółdzielczości nie ogranicza swojego literackiego żywota do prozy Pruszyńskiego. Pojawiła się choćby we wspomnianych już Wertepach czy powieści Igora Newerlego pt. Wzgórze błękitnego snu (1986).

Trudno chyba zaobserwować na łamach „Dzienników Kuratoryjnych” zainteresowanie spółdzielczością, a jeszcze trudniej byłoby mieć o brak takiego zainteresowania pretensje. Jest co prawda w nich mowa o działającej w Warszawie Wiejskiej Spółdzielni Kinematograficznej, „która postawiła sobie za zadania prowadzenie za pomocą filmu akcji oświatowo-kulturalnej i zawodowo-rolniczej wśród ludności wiejskiej" ${ }^{63}$. Ale nie ma chyba ona wiele wspólnego z formami przedsiębiorczości wspominanej przez Pruszyńskiego i Piątkowskiego. Być może spółdzielczość czy kooperatywy nie były celem, do którego zmierzać powinno wołyńskie czy poleskie rolnictwo i nie było potrzeby, by o tej idei mówić młodzieży. Pod koniec dwudziestolecia wołyńskie kuratorium starało się krzewić zupełnie inne idee. Były to m.in. idea obronności, w ramach której wyjaśniano, jak podczas takich przedmiotów jak: historia, język polski, śpiew, geografia, przyroda, matematyka, zajęcia praktyczne i rysunek oraz ćwiczenia cielesne nauczyciele powinni poruszać zagadnienia związane z obronnością państwa ${ }^{64}$ oraz idea kolonializmu uobecniająca się w Konkursie kolonialnym dla młodzieży. Konkursowe zadania były uzależnione do wieku uczestników. Dla młodzieży szkół powszechnych oraz I i II klasy gimnazjów konkursowe polecenie brzmiało: „Zrób model osiedla kolonisty polskiego: w Ameryce Północnej lub Południowej albo w Afryce. Wykonaj model $\mathrm{w}$ ten sposób, aby można było poznać, jak wygląda takie osiedle (dom mieszkalny wraz $\mathrm{z}$ otoczeniem, rośliny $\mathrm{w}$ ogrodzie i na polu, narzędzia rolnicze, zwierzęta i t.d.). Materiał i wielkość modelu dowolne". Nieco inny stopień trudności był wpisany w zadania dla młodzieży gimnazjalnej klas III i IV: „Gdyby to od ciebie zależało, to gdzie wybrałbyś kolonię dla Polski i jak wielką? Odpowiedź powinna być uzasadniona wszechstronnie

\footnotetext{
61 A. Piątkowski, Spółdzielczość socjalistów i chłopów, Warszawa 1938.

62 Ż. Marszałek-Trzebińska, Ksiądz Wacław Bliziński i jego dzieło na rzecz rodziny wiejskiej $w$ Liskowie (1870-1944), „Wychowanie w Rodzinie” 2018, nr 2, s. 27.

63 „Dziennik Urzędowy Kuratorium Okręgu Szkolnego Poleskiego” 1939, nr 4.

64 A. Skowroński, Zagadnienia obronności Państwa w nauczaniu i wychowaniu w szkole powszechnej, „Dziennik Urzędowy Kuratorium Okręgu Szkolnego Wołyńskiego” 1939, nr 4, s. 111-120.
} 
i objaśniona odpowiednimi mapami i wykresami i brać pod uwagę możliwość uzyskania danego terenu".

Informacja o konkursie i artykuł poświęcony zagadnieniom obronności ukazały się $\mathrm{w}$ kwietniowym numerze wołyńskiego dziennika kuratoryjnego ${ }^{65}$. Konkurs miał być rozstrzygnięty $\mathrm{w}$ Warszawie $\mathrm{w}$ maju, a więc zwycięzcy zdążyli prawdopodobnie odebrać nagrody albo przynajmniej się $\mathrm{z}$ nich ucieszyć6 ${ }^{66}$. Lekcji zaprojektowanych według rozkładu materiału uwzględniającego zagadnienia obronności chyba żaden nauczyciel w Polsce nie zdążył już przeprowadzić. Po wojnie na terenie Wołynia, Polesia i wielu innych regionów pojawiły się formy rolnej gospodarki uspołecznionej, którym było bardzo daleko do wzorów duńskich.

\section{Bibliografia}

Bakuła Bogusław (2006), Kolonialne i postkolonialne aspekty polskiego dyskursu kresoznawczego (zarys problematyki), „Teksty Drugie", nr 6, s. 11-33.

Beauvois Daniel (2005), Trójkąt ukraiński. Szlachta, carat i lud na Wotyniu, Podolu i Kijowwszczyźnie 1793-1914, przeł. K. Rutkowski, Lublin: UMCS.

Bojowniczka przyszłości [Godło: Rzeczywistość] (1935), „Słowo”, nr 35, s. 2-3.

Buczkowski Leopold (1973), Wertepy, Kraków: Wydawnictwo Literackie.

Cat-Mackiewicz Stanisław (1931), Myśl w obcęgach. Studia nad psychologia społeczeństwa Sowietów, Warszawa: F. Hoesick.

Cat [Cat-Mackiewicz Stanisław] (1935), Z dżdżystej doli. Wrażenia i wnioski po przysłaniu na konkurs nowel nauczycielskich, "Słowo", nr 23, s. 1.

Cholewińska Katarzyna (2015), Wszyscy jesteśmy Kalibanami: (post)kolonialne wizje latynoamerykańskiego podporządkowania, „Annales Universitas Marie Curie-Skłodowska", nr 1, s. 91-102.

„Dziennik Urzędowy Kuratorium Okręgu Szkolnego Poleskiego" (1929), nr 1, s. 25$-26$.

„Dziennik Urzędowy Kuratorium Okręgu Szkolnego Poleskiego" (1939), nr 4, s. 168.

Gehenna inteligenta na Kresach Wschodnich. „Nie trzeba nawuki”. Co odstaniaja reportaże z życia szkoły powszechnej (1935), „ABC Nowiny Codzienne", nr 46, s. 5.

Gosk Hanna (2008), Polski dyskurs kresowy w niefikcjonalnych zapisach międzywojennych. Próba lektury w perspektywie postcolonial studies, „Teksty Drugie”, nr 6, 20-33.

Grodecki Józef (2001), Program nauczania języka polskiego w szkole średniej. Metody i wyniki, w: Teoria kształcenia literackiego w latach 1918-1939. Antologia, red. L. Jazownik, cz. 1, Zielona Góra: Uniwersytet Zielonogórski, s. 198-204.

65 „Dziennik Urzędowy Kuratorium Okręgu Szkolnego Wołyńskiego” 1939, nr 4, s. 107.

66 Wśród nagród były m.in. Rejs jachtem Zawisza Czarny, trzydniowa wycieczka morska na $\mathrm{m} / \mathrm{s}$ „Piłsudski” lub m/s „Batory”, udział w kursie żeglarskim. 
Ile zarabiaja Urzędnicy. Premier - minister - wojewoda - starosta (1929), "Głos Poranny", nr 312, s. 7.

Konkurs Kolonialny dla Młodzieży (1939), „Dziennik Urzędowy Kuratorium Okręgu Szkolnego Wołyńskiego", nr 4, s. 107.

Kopeć Zbigniew (2018), Kobieta na bagnach, w: Z. Kopeć, W cieniu historii. Dwudziestowieczne doświadczenia i narracje, Poznań: Wydawnictwo Naukowe UAM, s. $107-117$.

Kostro Karol (1926), Do ogółu nauczycielstwa wołyńskiego, „Dziennik Urzędowy Kuratorium Okręgu Szkolnego Wołyńskiego", nr 10, s. 1.

Kraszewski Józef Ignacy (1859), Wieczory wołyńskie, Lwów: Drukarnia Zakładu Ossolińskich.

Mackiewicz Józef (1938), Bunt rojstów, Wilno: „Słowo”.

Marszałek-Trzebińska Żaneta (2018), Ksiądz Wacław Bliziński i jego dzieło na rzecz rodziny wiejskiej w Liskowie (1870-1944), „Wychowanie w Rodzinie” nr 2, s. 17-30.

Mędrzecki Włodzimierz (2008), Polacy i ich Wołyń, „Niepodległość i Pamięć”, nr 27, s. $125-151$.

Obrębski Józef, (2007), Polesie, red. nauk i wstęp A. Engelking, t. 1, Warszawa: Oficyna Naukowa.

Ossendowski Ferdynand Antoni (1935), Nauczycielka. Powieść, Poznań: Wydawnictwo Polskie R. Wegner.

Ossendowski Ferdynand Antoni (1935), Polesie, Poznań: Wydawnictwo Polskie R. Wegner.

Ossendowski Ferdynand Antoni (1936), Huculszczyzna. Gorgany i Czarnohora, Poznań: Wydawnictwo Polskie R. Wegner.

Piątkowski A. (1938), Spótdzielczość socjalistów i chłopów, Warszawa [nakład autora].

Polska Macierz Szkolna na Wołyniu (1938), Równe: Wydawnictwo Wołyńskiego Zarządu Polskiej Macierzy Szkolnej.

Pruszyński Ksawery (1936), Prawo do Wołynia, „Wiadomości Literackie”, nr 43, s. 3.

Pruszyński Ksawery (1938), Pomyśl o Wołyniu, w: U. Samczuk, Wołyń, przeł. T. Hollender, Warszawa: Towarzystwo Wydawnicze „Rój”, s. 5-8.

Pruszyński Ksawery (1966), Czarna księga niszczenia Wołynia. Z dziejów walki z kultura, w: K. Pruszyński, Podróże po Polsce. Podróże po Europie, Kraków: Wydawnictwo Literackie, s. 92-99.

Pruszyński Ksawery (2000), Był to niegdyś kraj bogaty, w: K. Pruszyński, Wspomnienia, reportaże, artykuly, t. 1, Warszawa: Twój Styl, s. 209-225.

Pruszyński Ksawery (2000), Na czarnym szlaku, w: K. Pruszyński, Wspomnienia, reportaże, artykuły, t. 1, Warszawa: Twój Styl, s. 17-60.

Retamar Roberto Fernández (1983), Kaliban, przeł. H. Czarnocka, w: R.F. Retamar, Kaliban i inne eseje, Kraków: Wydawnictwo Literackie, s. 5-68.

Samczuk Ułas (1938), Wołyń, przeł. T. Hollender, Warszawa: Towarzystwo Wydawnicze "Rój”.

Sanojca Karol (2013), Relacje polsko-ukraińskie w szkolnictwie państwowym południowo-wschodnich województw Drugiej Rzeczypospolitej, Kraków: Historia Iagellonica.

Shakespeare Wiliam (1993), Burza, przeł. S. Barańczak, Kraków: Znak. 
Siedlecka Jadwiga (1929), Dziecko poleskie. Konkurs Kuratorium Okręgu Szkolnego Poleskiego, „Dziennik Urzędowy Kuratorium Okręgu Szkolnego Poleskiego”, nr 7, s. 308-318.

Sikora Wincenty (1926), W sprawie obchodów rocznicy Konstytucji 3 maja, „Dziennik Urzędowy Kuratorium Okręgu Szkolnego Wołyńskiego", nr 3, s. 65-68.

Skowroński Aleksander (1939), Zagadnienia obronności Państwa w nauczaniu i wychowaniu w szkole powszechnej, „Dziennik Urzędowy Kuratorium Okręgu Szkolnego Wołyńskiego", nr 4, s. 111-120.

Sydow Marian (1927), Nauczyciel jako czynnik kulturalny na wsi, „Dziennik Urzędowy Kuratorium Okręgu Szkolnego Poleskiego" nr 1/2, s. 91-95.

Szer-Szeń [pseudonim] (1929), Liga Morska i Rzeczna, „Dziennik Urzędowy Kuratorium Okręgu Szkolnego Poleskiego", nr 5, s. 246-247.

Tumski Ryszard [pseudonim] (1935), Zostałem nauczycielem, „Słowo”, nr 32, s. 3.

Walasek Stefania (2006), Szkolnictwo powszechne na ziemiach północno-wschodnich II Rzeczypospolitej (1915-1939), Kraków: Oficyna Wydawnicza Impuls.

Węgrzyn Marta (2012), Dylematy tradycjonalisty - wątpliwości reformatora - samotność twórcy. "Wieczory wołyńskie” Józefa Ignacego Kraszewskiego, „Wiek XIX. Rocznik Towarzystwa Literackiego im. Adama Mickiewicza", nr 1, s. 321-341.

Wyka Marta (2019), Pisarstwo Ksawerego Pruszyńskiego. Biograficzność, gatunkowość, teorie recepcji, w: Zagadkowy Ksawery Pruszyński, red. B. Gautier, M. Urbanowski, Kraków: Wydawnictwo Uniwersytetu Jagiellońskiego, s. 109-113.

Wysz. [Wyszomirski J.] (1935), Nad lektura nowel konkursowych, „Słowo", nr 29, s. 2.

Zaleski Czesław (1932), Józef Piłsudski w pieśni starszego pokolenia i młodzieży, „Dziennik Urzędowy Kuratorium Okręgu Szkolnego Wołyńskiego", nr 3, s. 95-102.

Ziątek Zygmunt (1972), Ksawery Pruszyński, Warszawa: Państwowy Instytut Wydawniczy.

\title{
May You Teach Other People's Children in Wołyń and Polesie: About Schools in the Eastern Regions of Interwar Poland
}

\begin{abstract}
The article attempts to analyze the functioning of Polish schools in the interwar period in the eastern regions of the Second Polish Republic. The common stereotypes, rooted also in literature, projected a popular image of backwardness, in comparison with the population from other parts of Poland. For that reason, education was determined as a high priority after 1918. The schools in eastern regions, beside performing their educational function, also disseminated information and political propaganda. The teaching conditions in such schools were also complex, given the national and ethnic composition of children. Ksawery Pruszyński in his reportage Prawo do Wotynia demonstrates that not all efforts were equally satisfactory.
\end{abstract}

Keywords: reportage, education, propaganda, schooling, the Second Polish Republic 